\title{
Corporate Governance and Company Value: A Manufacturing Industry Case Study
}

\author{
Helma Malini \\ Universitas Tanjungpura, Indonesia \\ Dyen Natalia \\ Universitas Tanjungpura, Indonesia \\ Giriati \\ Universitas Tanjungpura, Indonesia \\ Email:helma.malini@ekonomi.untan.ac.id
}

\begin{abstract}
The purpose of this research is to look into the impact of corporate governance in the Indonesia Stock Exchange's Manufacturing Industry. Panel data from 73 Manufacturing Industry companies on the Indonesia Stock Exchange from 2014 to 2018 with a total of 365 observations of data whose research results were analyzed using panel data regression analysis with the Random Effect Model approach. Institutional ownership has a positive effect on Tobin's q and market book value, according to the study's findings. Tobin's $\mathrm{q}$ and market book value are negatively affected by foreign ownership. Meetings of the Board of Commissioners and the Audit Committee have a negative impact on stock price returns. Meetings of the board of directors, audit committee, and board of commissioners were found to have no impact on the value of the company. On the basis of these findings, it can be concluded that the results of testing the independent variables on the dependent are inconclusive and should be questioned further.
\end{abstract}

Keywords: good corporate governance, stock return, tobin's q, market book value

\section{Introduction}

Corporate governance has a significant impact on a company's competitiveness. Companies that implement sustainable corporate governance can have an impact on the company's value. Corporate governance is aided by the digitalization era, which encourages the strengthening and adaptability of corporate management in the short and long term. The company's value is a reflection of the company's current state as well as investors' perceptions of the company's value and prospects in the present and future. Value is also an important indicator for all parties when it comes to the company's future prospects and viability. According to Keown, Scott, Martin, and Petty (2001), company value is the stock market price that reflects a business's net worth.

As a result of lax legal, auditing, and accounting regulations, poor banking system, and a lack of concern from the board of directors for minority shareholders, corporate governance became an issue in the 1990s. In 1998, during a prolonged crisis in Indonesia, the issue of corporate governance came to light. Aside from the financial crisis, companies failed due to poor management, disregard for regulations, and corruption, collusion, and nepotism. In 1998, the Jakarta Stock Exchange proposed improving listing regulations to include an independent 
commissioner and audit committee. Depuis then, corporate governance has become a focus for governments, businesses, investors, and researchers alike.

Corporate governance is the process of ensuring that managers and other insiders act in ways that protect the interests of stakeholders (Velnampy, 2013). Corporate governance practices have evolved as a means of resolving agency conflicts that arise when there is a separation between owners and managers as parties in charge of the company (Lozano et al., 2016). Furthermore, corporate governance can affect the company's value in two ways. First, good corporate governance can lead to an increase in stock prices because investors anticipate the company's cash flow will be lower and the majority of profits earned will be distributed in the form of dividends.(Jensen \& Meckling, 1976); Second, as a result of monitoring costs and audit fees, good corporate governance can reduce the firm's return on equity (Shleifer \& Vishny, 1997).

Corporate governance implementation in Indonesia is still being studied and researched. Whereas in recent years, cases of corporate governance violations have continued to occur and harm various related parties. Violations of corporate governance are a problem not only in state-owned enterprises, but also in private enterprises in Indonesia. Whereas professionalism and a good track record, particularly integrity, should be important considerations in the company's board of directors placement. This requires more attention in order to reduce conflicts of interest and governance violations, which have a negative impact on stakeholder trust and the long-term viability of the company in question.

The relationship between corporate governance has received a great deal of attention both in Indonesia and abroad. However, research results are still inconclusive and have research gaps, such as research results. (Al-Khouri, 2005; Buallay, Hamdan, \& Zureigat, 2017; Ngatemin, Maksum, Erlina, \& Sirojuzilam, 2018; Oktari, Melas \& Zarefar, 2018; Thanatawee, 2014) where the measurement variables of internal and external corporate governance mechanisms were used, a different relationship on the company's value was obtained.

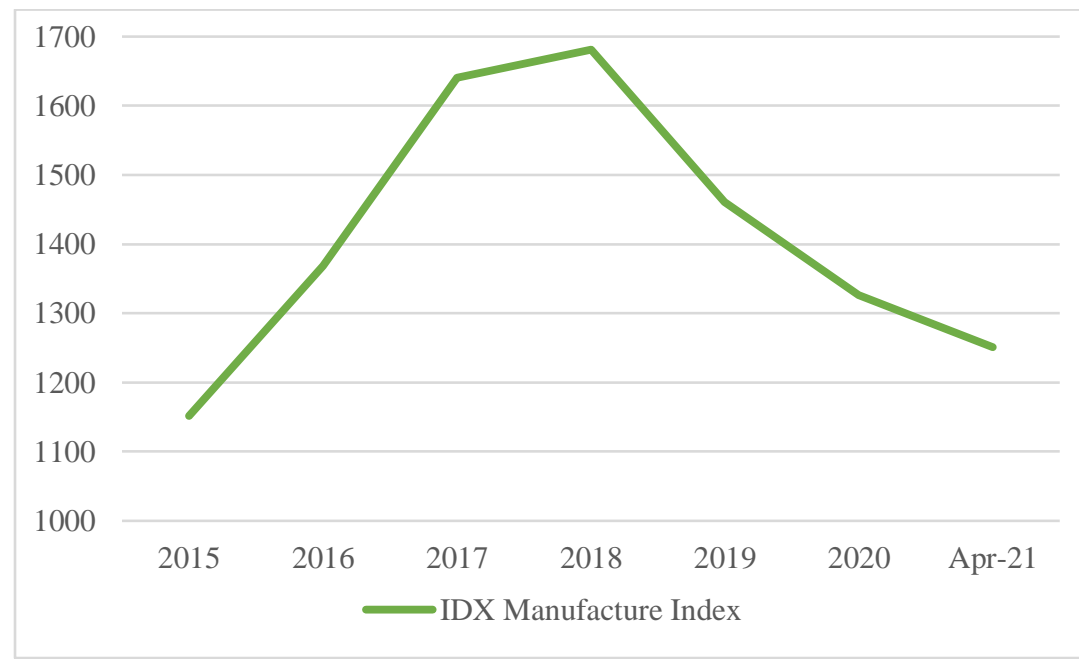
Figure 1. Yearly Movement of Manufacturing Sector in Indonesia Stock
Exchange

This research will look into corporate governance in the manufacturing industry. Based on Figure 1, manufacturing is one of the primary sectors that contribute to economic growth. Indonesia's manufacturing industry has grown steadily over the last five years and peaked in 2016-2018. However, one thing that is concerning is that following 2018, the movement of 
manufacturing stock prices has been downward. The Decline in the manufacturing sector's contribution to Indonesia's GDP over the last decade, even claiming that the country has entered an era of deindustrialization.

The manufacturing industry's low competitiveness and the perception that inefficiency is to blame for the industry's suboptimal performance in Indonesia. Based on empirical evidence (Fauzia, 2010; Hardiyanto, 2010; Rahman, 2010), the industrial sector in Indonesia has historically lagged behind other countries in the Asia Pacific region in terms of technology contribution to growth. Significant issues affecting the manufacturing industry in in Indonesia, for example, there is a problem of inefficiency in the operation and management of the industry, as well as the occurrence of inequality, which results in inefficiency and lowers the company's value (Malini, 2021; Silalahi, 2014).

This research examines the effect of good corporate governance on the performance of industrial companies, which in turn affects the company's value on the stock exchange floor. This research will inform the policies that will be implemented to advance the manufacturing industry in Indonesia, benefiting both businesses and investors, as well as economic growth.

\section{Literature Review}

The company's value is an integral part of its establishment. Every aspect of management, decision-making, performance, and company prospects is reflected in the company's value, which is assessed from both the internal and external perspectives. To increase the value of the business, owners and managers must share a common goal and be capable of making sound financial decisions and implementing sound corporate governance. The ownership structure plays a role in the development of corporate governance and managerial control. (AlQadasi \& Abidin, 2018).

Generally speaking, corporate governance refers to an organization's management structure and procedures that are based on the principle of accountability and that have the potential to increase the value of the company in the long run. (Velnampy, 2013) because a strong governance system results in improved procedures and oversight of activities. company. Additionally, the ownership structure of the business can be a factor in determining the degree of control exercised by internal parties and external parties such as investors. (Lemmon \& Lins, 2003). The following is a description of the test of the influence between variables and the development of research hypotheses:

\section{Institutional Ownership on Firm Value}

Institutional ownership is the proportion of company shares owned by nonindividual institutions or institutions (Hery, 2017). Institutional ownership plays an important role in management supervision because, in addition to holding a disproportionately large proportion of the company's stock, institutional investors are typically comprised of a number of different institutions, allowing for a more optimal level of control or supervision to be provided. Because the proportion of institutional ownership is higher, the supervision is more stringent. This helps to reduce instances of management actions that are detrimental to the company. Investors are also more confident in the company, which will have an impact on the company's value by increasing the value of the company's stock.

In a study conducted by (Mak \& Kusnadi, 2005; Wei et al., 2005), institutional ownership was found to affect firm value. However, different results were found by (AlKhouri, 2005; Mishra \& Kapil, 2017; Ngatemin et al., 2018; Thanatawee, 2014), where institutional ownership was found to have a positive effect on firm value. Based on the description above, the first hypothesis developed is as follows: 


\section{$\boldsymbol{H}_{1}:$ Institutional ownership affects the value of the company}

\section{Foreign Ownership on Firm Value}

Individuals or institutions from other countries may hold shares in the company, which is known as foreign ownership. In order to achieve abnormal returns or higher returns than their home countries, foreign investors typically invest in companies located outside of their home countries. As a result, institutional investors are more selective in the investments they make. When a company is owned by a foreign entity, the control and supervision of management and company performance will inevitably become more stringent. As a result, foreign investors will demand strong performance and will send out positive signals to encourage other investors to join in. Furthermore, foreign investors are extremely concerned about the importance of corporate governance and environmental sustainability, which will encourage other investors to join in.

In a study conducted by Thanatawee, (2014), foreign ownership was found to have a negative effect on firm value. Different results were found in studies (Ferris \& Park, 2005; Wei et al., 2005), where foreign ownership was found to increase firm value. Based on the description above, the second hypothesis is developed as follows:

$\mathrm{H}_{2}$ : Foreign ownership affects the value of the company

\section{Board of Directors on Firm Value}

The Board of Directors is the management group in charge of overseeing and being accountable for the operation of the company in accordance with the company's objectives. A disproportionately large number of directors on the board of directors can have an impact on the inefficiency of the decision-making process, which in turn can have an impact on the declining performance of the company, resulting in a decrease in the value of the company. A common cause of this is a decreased ability of the board of directors to control management as a result of the large size of the organization, which has an impact on communication problems. (Yermack, 1996).

In a study conducted (Kota \& Tomar, 2010; Kumar \& Singh, 2013; Mak \& Kusnadi, 2005) board size was found to have a negative effect on firm value. Positive results were found in research (Buallay et al., 2017; Lidyah et al., 2019), in addition (Adawi \& Rwegasira, 2013; Bhat et al., 2018) revealed that the size of the company's board does not affect firm value. Based on the description above, the third hypothesis developed is as follows: $\mathrm{H}_{3}:$ The size of the board of directors affects the value of the company

\section{Board of Commissioners on Company Value}

The board of commissioners is the body in charge of overseeing and advising the board of directors on all matters pertaining to the corporation. The Board of Commissioners is tasked with ensuring that the company's strategy is implemented, supervising management's performance in managing the company, and requiring the implementation of accountability measures in the company.(Lidyah et al., 2019). The large size of the board of commissioners will have an impact on the more effective control over the board of directors and management of the company and keep the company running according to its objectives.

The results of research conducted by (Gosal et al., 2018; Oktari et al., 2018) found that there was no relationship between the size of the board of commissioners and firm value. However, (Lidyah et al., 2019; Siallagan \& Machfoedz, 2006) found that the size of the board of commissioners has a positive impact on firm value. Based on the description above, the fourth hypothesis is developed as follows:

$\mathrm{H}_{4}$ : The size of the board of commissioners affects the value of the company 


\section{Audit Committee on Company Value}

All members of the audit committee are third-party independent contractors who have no affiliation with the company they serve on. The audit committee is one of the parties that has an important role to play in the governance of a company's affairs. In addition, because the audit committee serves as a link between the company's management and the board of commissioners as well as other external parties, its size has an impact on the effectiveness and efficiency of management supervision in the company.

The results of research studies conducted (Obradovich \& Gill, 2013; Rouf, 2011; Tornyeva \& Wereko, 2012) found a positive relationship between audit committee size and firm value. Based on the description above, the fifth hypothesis is developed as follows:

$\mathrm{H}_{5}:$ The size of the audit committee affects the value of the company

\section{Board of Commissioners Meeting on Company Value}

The number of meetings held by the board of commissioners in a given year is used to calculate the number of meetings held by the board of commissioners in the following year. The number of board meetings will increase the burden on the company, but the board of commissioners will have more time to set strategy and monitor management activities as a result of the increased number of meetings.

In addition, increasing the number of board of commissioners meetings can improve the effectiveness of supervision and decision-making, allowing the board of commissioners to provide input more quickly on problems that arise within the organization.he important key for the board of commissioners in carrying out supervision and effectiveness of management is the number of meetings they have held (Jensen, 1993). The results of research conducted by (Ntim \& Osei, 2011) found a positive impact on the frequency of board of commissioners' meetings on firm value. Based on the description above, the sixth hypothesis was developed as follows: $\boldsymbol{H}_{6}:$ The frequency of the board of commissioners meeting affects firm value

\section{Audit Committee Meeting on Company Value}

It is critical to increase the number of audit committee meetings held in order to improve the effectiveness of the company's management oversight. Audit committee meetings held on a regular basis can improve the effectiveness of supervision in making decisions related to the company's internal control system, thereby improving management discipline. Audit committees that hold more meetings have more time to oversee the financial reporting process, identify management risks, and monitor internal controls, all of which contribute to the increase in the value of the company.

The result of studies conducted (Al-matari et al., 2012; Beasley et al., 2000). It was discovered that increasing the frequency of audit committee meetings had a positive impact on the value of the company. The following is the seventh hypothesis that has been developed in light of the foregoing description:

$\boldsymbol{H}_{7}:$ The frequency of audit committee meetings affects firm value 


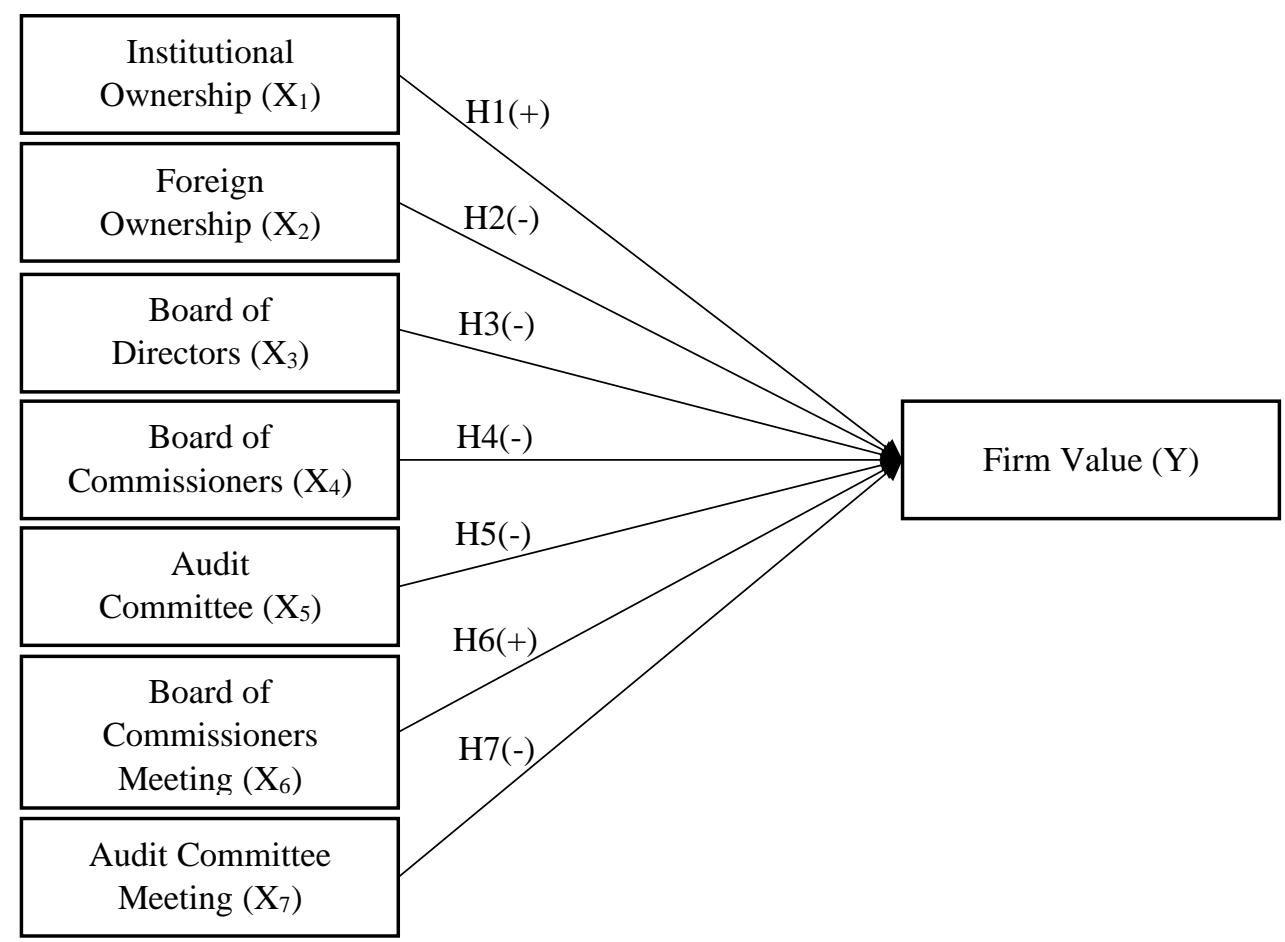

Figure 2. Research Framework

\section{Research Method}

This research is quantitative against manufacturing companies in the Indonesia Stock Exchange period 2014 to 2018 . The research population is 183 companies. Determination of the sample is done by using a purposive sampling technique, to obtain 73 sample companies. The data analysis technique used in this research is panel data regression analysis. According to Basuki and Prawoto (2016), in determining the estimation of the panel data regression model, it can be done through three approaches, namely the common effect model, fixed-effect model, and random effect model. In addition, to determine the most appropriate model should be tested chow, test Hausman and test Lagrange multiplier.

Table 1. Variable Measurement

\begin{tabular}{|c|c|}
\hline Variable & Measurement \\
\hline \multicolumn{2}{|l|}{ Dependent Variable } \\
\hline Stock Return (SR) & Market price growth rate \\
\hline Tobin’s Q (TQ) & $\begin{array}{l}\text { Market capitalization }+ \text { current debt - current } \\
\text { assets }+ \text { long term debt per total assets }\end{array}$ \\
\hline Market Book Value (MBV) & Share market price per share book value \\
\hline \multicolumn{2}{|l|}{ Independent Variable } \\
\hline Institutional Ownership (IO) & $\begin{array}{l}\text { Percentage of institutional ownership per number } \\
\text { of shares outstanding }\end{array}$ \\
\hline Foreign Ownership (FO) & $\begin{array}{l}\text { Percentage of foreign ownership per number of } \\
\text { shares outstanding }\end{array}$ \\
\hline Board of Directors (BD) & Number of the board of directors \\
\hline Board of Commissioners (BC) & Number of commissioners \\
\hline Audit Committee (AC) & Number of the audit committee \\
\hline
\end{tabular}




\begin{tabular}{|l|l|}
\hline $\begin{array}{l}\text { Frequency of Board Meetings } \\
\text { (FBM) }\end{array}$ & $\begin{array}{l}\text { Frequency/number of board of commissioners } \\
\text { meetings }\end{array}$ \\
\hline $\begin{array}{l}\text { Frequency of Audit Committee } \\
\text { Meetings (ACM) }\end{array}$ & Frequency/number of audit committee meetings \\
\hline Control Variable & \\
\hline Company Size (Size) & Natural logarithm of total assets \\
\hline Profitability (ROE) & Net profit per own capital \\
\hline
\end{tabular}

The following research model developed in this study:

$\mathrm{SR}_{\text {it }}=\propto+\beta_{1} \mathrm{IO}_{\mathrm{t}}+\beta_{2} \mathrm{FO}_{\mathrm{t}}+\beta_{3} \mathrm{BD}_{\mathrm{t}}+\beta_{4} \mathrm{BC}_{\mathrm{t}}+\beta_{5} \mathrm{AC}_{\mathrm{t}}+\beta_{6} \mathrm{FBM}_{\mathrm{t}}+\beta_{7} \mathrm{ACM}_{\mathrm{t}}+\varepsilon_{\mathrm{t}} \ldots . .(1)$

$\mathrm{TQ}_{\mathrm{it}}=\propto+\beta_{1} \mathrm{IO}_{\mathrm{t}}+\beta_{2} \mathrm{FO}_{\mathrm{t}}+\beta_{3} \mathrm{BD}_{\mathrm{t}}+\beta_{4} \mathrm{BC}_{\mathrm{t}}+\beta_{5} \mathrm{AC}_{\mathrm{t}}+\beta_{6} \mathrm{FBM}_{\mathrm{t}}+\beta_{7} \mathrm{ACM}_{\mathrm{t}}+\varepsilon_{\mathrm{t}} \ldots$. (2)

$\mathrm{MBV}_{\text {it }}=\propto+\beta_{1} \mathrm{IO}_{\mathrm{t}}+\beta_{2} \mathrm{FO}_{\mathrm{t}}+\beta_{3} \mathrm{BD}_{\mathrm{t}}+\beta_{4} \mathrm{BC}_{\mathrm{t}}+\beta_{5} \mathrm{AC}_{\mathrm{t}}+\beta_{6} \mathrm{FBM}_{\mathrm{t}}+\beta_{7} \mathrm{ACM}_{\mathrm{t}}+\varepsilon_{\mathrm{t}}$ (3)

\section{Result and Discussion}

According to Table 1, the value of the average return of shares, which amounts to 35.36 percent, demonstrates that the average market movement relative worth is positive on an annualized basis. Tobin's q has an average value of 2.94 on the scale. Conversely, the average market book value is -31.37 , indicating that the average company is in the negative. A 72 percent average value of institutional ownership indicates that institutions constitute the vast majority of company shareholders, and foreign ownership of companies accounts for 49 percent of the average value of institutional ownership. The average size of the board of directors, commissioners, and audit committee is approximately 5 to 3 people, and the average frequency of board of commissioners and audit committee meetings is 6 times per year. Finally, based on the standard deviation, the majority of the variables are stable and reliable in their performance over time.

Table 2. Descriptive Statistics

\begin{tabular}{|l|r|r|r|r|r|}
\hline Variable & \multicolumn{1}{|c|}{ Mean } & \multicolumn{1}{c|}{ Median } & \multicolumn{1}{c|}{ Max } & \multicolumn{1}{c|}{ Min } & \multicolumn{1}{c|}{ Std. Dev. } \\
\hline SR & 35.36 & -1.90 & 4400 & -99 & 288.86 \\
\hline TQ & 2.94 & 0.65 & 120.57 & -0.35 & 10.29 \\
\hline MBV & -31.37 & 1.11 & 1949.72 & -16490.56 & 871.99 \\
\hline IO & 0.72 & 0.82 & 0.99 & 0.01 & 0.27 \\
\hline FO & 0.49 & 0.53 & 0.99 & 0.00 & 0.30 \\
\hline BD & 5.27 & 5 & 18 & 2 & 2.71 \\
\hline BC & 4.36 & 3 & 13 & 2 & 2.01 \\
\hline AC & 3.11 & 3 & 5 & 2 & 0.40 \\
\hline FBM & 6.27 & 6 & 24 & 1 & 3.85 \\
\hline ACM & 6.33 & 4 & 38 & 2 & 4.88 \\
\hline
\end{tabular}

Table 2 shows the results of the model's feasibility testing. The results of the Chow, Hausman, and Lagrange Multiplier tests are used to determine the best research model between common effects, fixed effects, and random effects. According to the test results, the best research model for all research models is random effect.

$\mathrm{H}_{1}$ predicts the influence of institutional ownership on firm value. The test results show institutional ownership has a positive and significant impact on the value of the company as measured by Tobin's $q$ and market book value so that $\mathrm{H}_{1}$ is accepted. These results explain 
that the internal mechanism of corporate governance in terms of ownership structure as measured by institutional ownership can provide supervisory control, signals, and a positive impact on firm value such as research results (Al-Khouri, 2005; Mishra \& Kapil, 2017; Ngatemin et al., 2018; Thanatawee, 2014). In addition, the existence of institutional ownership in the company's share ownership structure can also minimize agency problems that may occur and work as an outside monitor of management actions (Al-Khouri 2005). The results of this study show that institutional ownership has no effect on stock price returns, but it does have an effect on Tobin's q and market book value, as demonstrated by the tests. When it comes to institutional ownership, the majority of institutions prioritize long-term investment while still ensuring that stock prices remain stable. Institutional investors are more likely to evaluate the value of a company in terms of its long-term potential.

Tabel 3. Panel Regression Analysis

\begin{tabular}{|l|r|r|r|}
\hline Variable & Model 1 & Model 2 & Model 3 \\
\hline C & 1.72 & -5.70 & -57.66 \\
\hline IO & $(0.88)$ & $(0.68)$ & $(0.00)$ \\
\hline & 0.26 & $4.85^{*}$ & $0.45^{*}$ \\
\hline FO & $(0.72)$ & $(0.00)$ & $(0.01)$ \\
\hline & -0.82 & $-4.49^{*}$ & $-0.93^{*}$ \\
\hline BD & $(0.27)$ & $(0.01)$ & $(0.00)$ \\
\hline & -0.17 & -0.02 & -0.01 \\
\hline BC & $(0.27)$ & $(0.94)$ & $(0.89)$ \\
\hline & $-0.31^{*}$ & 0.33 & 0.00 \\
\hline AC & $(0.02)$ & $(0.26)$ & $(0.96)$ \\
\hline & -0.31 & 1.40 & -0.04 \\
\hline FBM & $(0.54)$ & $(0.20)$ & $(0.70)$ \\
\hline & 0.04 & -0.13 & 0.01 \\
\hline ACM & $(0.38)$ & $(0.23)$ & $(0.45)$ \\
\hline & -0.11 & -0.07 & -0.02 \\
\hline Size & $(0.08)$ & $(0.55)$ & $(0.26)$ \\
\hline & $1.04^{*}$ & 0.10 & $0.33^{*}$ \\
\hline ROE & $(0.03)$ & $(0.84)$ & $(0.00)$ \\
\hline & -0.27 & $1.91^{*}$ & -0.02 \\
\hline R-squared & $(0.37)$ & $(0.01)$ & $(0.75)$ \\
\hline Adjusted R-squared & 0.06 & 0.06 & 0.13 \\
\hline F-statistic & 0.04 & 0.04 & 0.11 \\
\hline Chow Test & 2.60 & 2.70 & 5.88 \\
\hline Hausman Test & $2266.13^{*}$ & $10.50^{*}$ & $4383.89^{*}$ \\
\hline LM Test & 10.877 & 10.37 & 2.52 \\
\hline Not & $679.68^{*}$ & $288.82^{*}$ & $718.27^{*}$ \\
\hline
\end{tabular}

Note: *) 5 percent

$\mathrm{H}_{2}$ predicts the effect of foreign ownership on the value of the company. $\mathrm{H} 2$ is accepted as a result of the test results, which show that foreign ownership has a negative and statistically significant impact on firm value as measured by Tobin's $q$ and market book value. These findings provide an explanation for why companies with foreign investors have lower firm values on average. These findings are consistent with those obtained through Thanatawee's 
research.. Thanatawee, (2014) explains that in Thailand companies with foreign investors have low firm value, where the level of control exerted is relatively low, is not active in monitoring managers, and may even take over company resources at the expense of minority shareholders. When it comes to exercising control over a company's management, foreign investors tend to pay more attention to the dividends that will be paid out than they do to the company's financial performance. Foreign investors also have a proclivity to hold onto their company's stock for an extended period of time.

$\mathrm{H}_{3}$ and $\mathrm{H}_{5}$ predict the effect of the size of the board of directors and the size of the audit committee on firm value. In the model studied, the size of the board of directors and the size of the audit committee were found to not affect firm value, so that $\mathrm{H}_{3}$ dan $\mathrm{H}_{5}$ was rejected. This result is in line with(Adawi \& Rwegasira, 2013; Bhat et al., 2018) where changes in the size of the board of directors do not affect firm value. This demonstrates that increasing the number and size of the board of directors and audit committee will not solve the agency problem in the company and will have no impact on the value of the company. A disproportionately large board of directors and audit committee has been shown to have a negative impact on the value of a company. Due to the fact that the supervision provided is still ineffective and inefficient, it will become a burden for the company if the size or number of employees grows significantly. In Indonesia, the selection and appointment of boards of directors, both in state-owned and privately held corporations, is less professional than in other countries. Several legal cases and violations of corporate governance involving the company's board of directors demonstrate this point. It is supported by research findings that are not statistically significant, and it demonstrates that investors do not take the company's leadership structure, particularly the directors and audit committee, into consideration when making investment decisions.

$\mathrm{H}_{4}$ predicts the influence of the size of the board of commissioners on the value of the company. In the model studied, the size of the board of commissioners was found to have a negative effect on firm value as measured in stock returns so that $\mathrm{H}_{4}$ was accepted. The size of the board of commissioners that is too large causes the decision-making process to run slower. This result is not in line with the results of research (Lidyah et al., 2019; Siallagan \& Machfoedz, 2006) According to the findings, the size of the board of commissioners has a positive impact on the value of the company. The negative relationship found between the size of the board of commissioners and the value of the company in this study demonstrates the ineffectiveness of the board of commissioners' size in controlling and supervising the management of the company, which is the board of commissioners' responsibility. When the results of control and company performance have a negative impact on the value of the company's stock return, this can also be interpreted as a negative signal.

$\mathrm{H}_{6}$ predicts the influence of the frequency of board meetings on corporate value. In the model examined, the frequency of board meetings found no effect on the value of the company so that $\mathrm{H}_{6}$ was rejected. The results of this study are not in line with the results of research (Jensen, 1993 dan Ntim \& Osei, 2011). This means that when it comes to investing in a company's stock, investors in Indonesia do not pay too much attention to the board of commissioners meeting. Furthermore, board of commissioner's meetings are typically held in closed session and are not broadcast to the general public. The number of meetings held as well as the context in which they were held can only be found in the annual report published after the year has ended.

$\mathrm{H}_{7}$ predicts the effect of the frequency of audit committee meetings on firm value. In the model studied, the frequency of audit committee meetings was found to have a negative effect on firm value as measured in stock returns so that $\mathrm{H}_{7}$ was accepted. The results of this study are not in line with the results found (Al-matari et al., 2012; Beasley et al., 2000) when the frequency of audit committee meetings is increased, it has a positive impact on the value 
of the company. This meeting's primary goal is to improve the efficiency with which management is supervised. When the frequency of meetings is excessive, however, it can send a negative signal to investors, indicating that the company is experiencing difficulties and that periodic meetings are required far too frequently.

Models 1, 2, and 3 each account for $4 \%$ of the influence of corporate governance variables on stock returns and Tobin's q, and $11 \%$ of company value as measured by market book value. Finally, the $\mathrm{F}$ value is statistically significant, indicating that the model is worthwhile of further investigation.

\section{Conclusions and Recommendations}

Some conclusions about the independent variables can be drawn based on the discussant. Tobin's $q$ and market book value both show that the percentage of institutional ownership has a positive effect on firm value. Second, as measured by Tobin's q and market book value, the percentage of foreign ownership has a negative impact on firm value. Third, whether measured by stock returns, Tobin's q, or market book value, the size of the board of directors, the size of the audit committee, and the frequency of board of commissioners' meetings have no effect on firm value. Fourth, the number of audit committee meetings and the size of the board of commissioners have a negative impact on stock returns.

According to the findings of the study, the board of directors should be considered when deciding on an investment because the board and management will be able to implement sustainable corporate governance if they have the necessary competence, capability, and commitment. Because this study was limited to manufacturing companies and focused on corporate governance variables, more research is needed to extend the study period and obtain consistency of influence over time. Further research is being done in other industries, as well as comparative tests on corporate governance in developing and Asian countries.

\section{References}

Adawi, M., \& Rwegasira, K. (2013). Corporate Governance and Firm Valuation in Emerging Markets: Evidence From UAE Listed Companies in the Middle East. Corporate Ownership and Control, 11(1), 637-656.

Al-Khouri, R. (2005). Corporate Governance and Firms Value in Emerging Markets: the Case of Jordan. Advances in Financial Economics, 11, 31-50. https://doi.org/10.1016/S15693732(04)11002-5

Al-matari, Y. A., Al-Swidi, A. K., Gadzil, F. H. B., \& Al-matari, E. M. (2012). Board of Directors, Audit Committee Characteristics and the Performance of Saudi Arabia Listed Companies Board of Directors, Audit Committee Characteristics and Performance of Saudi Arabia Listed Companies. International Review of Management and Marketing, 2(4), 241-251.

AlQadasi, A., \& Abidin, S. (2018). The Effectiveness of Internal Corporate Governance and Audit Quality: The Role of Ownership Concentration - Malaysian evidence. Corporate Governance (Bingley), 18(2), 233-253. https://doi.org/10.1108/CG-02-2017-0043

Beasley, M. S., Carcello, J. V, Hermanson, D. R., \& Lapides, P. D. (2000). Fraudulent Financial Reporting: Consideration of Industry Traits and Corporate Governance Mechanisms. American Accounting Association, 14(4), 441-454.

Bhat, K. U., Chen, Y., Jebran, K., \& Bhutto, N. A. (2018). Corporate Governance and Firm Value: a Comparative Analysis of State and Non-State Owned Companies in the Context of Pakistan. Corporate Governance (Bingley), 18(6), 1196-1206. 
https://doi.org/10.1108/CG-09-2017-0208

Buallay, A., Hamdan, A., \& Zureigat, Q. (2017). Corporate Governance and Firm Performance: Evidence from Saudi Arabia. Australasian Accounting, Business and Finance Journal, 11(1), 78-98. https://doi.org/10.14453/aabfj.v11i1.6

Fauzia, V. A. (2010). Pengaruh EVA (Economic Value Added), MVA (Market Value Added) dan ROI (Return on Investment) terhadap Harga Saham pada Perusahaan Manufaktur yang Listing di BEI periode 2005-2007. Diploma Thesis. Universitas Negeri Malang. Malang.

Ferris, S. P., \& Park, K. (2005). Foreign Ownership and Firm Value: Evidence From Japan. Advances in Financial Economics, 11, 1-29. https://doi.org/10.1016/S15693732(04)11001-3

Gosal, M. M., Pangemanan, S. S., \& Tielung, M. V. J. (2018). the Influence of Good Corporate Governance on Firm Value: Empirical Study of Companies Listed in Idx30 Index Within 2013-2017 Period. Jurnal EMBA: Jurnal Riset Ekonomi, Manajemen, Bisnis Dan Akuntansi, 6(4), 2688-2697. https://doi.org/10.35794/emba.v6i4.21050

Hardiyanto, H. O. (2010). Pengaruh Economic Value Added (EVA), Market Value Added (MVA), Return on Investment (ROI) dan Return on Equity (ROE) terhadap Harga Saham perusahaan Manufaktur yang listing di BEI periode 2006-2008. Skripsi. Universitas Negeri Malang. Malang.

Jensen, M. C. (1993). The Modern Industrial Revolution, Exit, and the Failure of Internal Control Systems. The Journal of Finance, 48(3), 831-880.

Jensen, M. C., \& Meckling, W. H. (1976). Theory of the Firm: Managerial Behavior, Agency Costs and Ownership Structure. Journal of Financial Economics, 3(4), 305-360. https://doi.org/https://doi.org/10.1016/0304-405X(76)90026-X

Kota, H. B., \& Tomar, S. (2010). Corporate Governance Practices in Indian firms. Journal of Management \& Organization, 16(2), 266-279. https://doi.org/10.1017/s1833367200002170

Kumar, N., \& Singh, J. P. (2013). Effect of Board Size and Promoter Ownership on Firm Value: Some Empirical findings from India. Corporate Governance (Bingley), 13(1), 88-98. https://doi.org/10.1108/14720701311302431

Lemmon, M. L., \& Lins, K. V. (2003). Ownership Structure, Corporate Governance, and Firm Value: Evidence from the East Asian Financial Crisis. Journal of Finance, 58(4), 14451468. https://doi.org/10.1111/1540-6261.00573

Lidyah, R., Amir, A., Yacob, S., \& Rahayu, S. (2019). The Effect of Board of Director, Board of Commissioner and Audit Committee on Value of Firm To Islamic Social Reporting As a Mediating Variable. Journal of Business Studies and Mangement Review, 2(2), 82-87. https://doi.org/10.22437/jb.v2i2.7214

Lozano, M. B., Martínez, B., \& Pindado, J. (2016). Corporate Governance, Ownership and Firm Value: Drivers of Ownership as a Good Corporate Governance Mechanism. International Business Review, 25(6), 1333-1343. https://doi.org/10.1016/j.ibusrev.2016.04.005

Mak, Y. T., \& Kusnadi, Y. (2005). Size really matters: Further evidence on the negative relationship between board size and firm value. Pacific-Basin Finance Journal, 13, 301318. https://doi.org/10.1016/j.pacfin.2004.09.002

Malini, H. (2021). Return Autocorrelations and Volatilities of Kuala Lumpur Shariah Compliance that Coincide with Big News in Malaysia. Management and Sustainable Development Journal, 3(1), 106-121.

Mishra, R., \& Kapil, S. (2017). Effect of Ownership Structure and Board Structure on Firm Value: Evidence from India. Corporate Governance: The International Journal of 
$\begin{array}{llll}\text { Business } & \text { in } & \text { Society, } & \text { 700-726. }\end{array}$ http://dx.doi.org/10.1108/14720701011069605\%5Cnhttp://dx.doi.org/10.1108/0951357 0810872978\%5Cnhttp://dx.doi.org/10.1108/cpoib-06-2013-0019

Ngatemin, Maksum, A., Erlina, \& Sirojuzilam. (2018). Effects of Institutional Ownership and Profitability to Firm Value with the Capital Structure as Intervening variable (Empirical study at company tourism industry sector listed in Indonesia). International Journal of Civil Engineering and Technology, 9(5), 1305-1320.

Ntim, C. G., \& Osei, K. A. (2011). The Impact of Corporate Board Meetings on Corporate Performance in South Africa. Munich Personal RePEc Archive, 2(2), 83-103.

Obradovich, J., \& Gill, A. (2013). The Impact of Corporate Governance and Financial Leverage on the Value of American Firms. International Research Journal of Finance and Economics, 91, 1-14.

Oktari, V., Mela, N. F., \& Zarefar, A. (2018). The Influence of Good Corporate Governance on Company Value in Jakarta Islamic Index Companies. Jurnal Akuntansi Keuangan Dan Bisnis, 11(1), 69-78.

Rahman, T. F. (2010). Pengaruh Return On Equity (ROE), Earning Per Share (EPS), Dividen Payout Ratio (DPR), terhadap Harga Saham pada Perusahaan Manufaktur yang Listing di BEI periode 2005-2007. Skripsi. Universitas Negeri Malang. Malang.

Rouf, A. (2011). The Relationship between Corporate Governance and Value of the Firm in Developing Countries: Evidence from Bangladesh. The International Journal of Applied Economics and Finance, 5(3), 237-247.

Shleifer, A., \& Vishny, R. W. (1997). A Survey of Corporate Governance. The Journal Of Finance, 52(2), 737-783.

Siallagan, H., \& Machfoedz, M. (2006). Mekanisme Corporate Governance, Kualitas Laba,dan Nilai Perusahaan. Simposium Nasional Akuntansi 9 Padang, 23-26.

Silalahi, S. A. F. (2014). Kondisi Industri Manufaktur Indonesia Dalam Menghadapi Globalisasi. Jurnal Ekonomi \& Kebijakan Publik, 5(1), 1-13.

Thanatawee, Y. (2014). Institutional Ownership and Firm Value in Thailand. Asian Journal of Business and Accounting, 7(2), 1-22. https://papers.ssrn.com/sol3/papers.cfm?abstract_id=2543058

Tornyeva, K., \& Wereko, T. (2012). Corporate Governance and Firm Performance : Evidence from the Insurance Sector of Ghana. European Journal of Business and Management, 4(13), 95-113.

Velnampy, P. T. (2013). Corporate Governance and Firm Performance : A Study of Sri Lankan Manufacturing Companies. Journal of Economics and Sustainable Development, 4(3), 228-236.

https://pdfs.semanticscholar.org/5443/5d35d0059bed3b1c1fee1723a353df25b8f4.pdf

Wei, Z., Xie, F., \& Zhang, S. (2005). Ownership Structure and Firm Value in China' s Privatized Firms : 1991 - 2001. Journal of Financial and Quantitative Analysis, 40(1), 87-108.

http://citeseerx.ist.psu.edu/viewdoc/download?doi=10.1.1.587.789\&rep=rep1\&type=pdf

Yermack, D. (1996). Higher Market Valuation of Companies with a Small Board of Directors. Journal of Financial Economics, 40(2), 185-211. https://doi.org/https://doi.org/10.1016/0304-405X(95)00844-5 